Original Research Paper

\title{
Pengaruh Jenis Mulsa dan Dosis Pupuk NPK terhadap Pertumbuhan dan Hasil Tanaman Terong Hijau (Solanum melongena L)
}

\author{
Ahmad Raksun ${ }^{\text {* }}$, Lalu Japa ${ }^{1}$, I. Gde Mertha ${ }^{1}$ \\ ${ }^{1}$ Program Studi Pendidikan Biologi, Jurusan PMIPA FKIP Universitas Mataram
}

\section{Riwayat artikel}

Received: 02 April 2019

Revised: 08 Juli 2019

Accepted: 10 Juli 2019

Published : 14 Agustus 2019

*Corresponding Author: Ahmad Raksun, Program Studi Pendidikan Biologi, Jurusan PMIPA FKIP Universitas Mataram. Mataram, Indonesia. Email:

ahmadunram@unram.ac.id

\begin{abstract}
Abstrak : Upaya peningkatan pertumbuhan dan hasil tanaman dapat dilakukan dengan penggunaan mulsa dan pemupukan tanaman. Salah satu pupuk sintetik yang dapat digunakan untuk meningkatkan pertumbuhan dan hasil tanaman adalah pupuk NPK. Penelitian tentang pengaruh jenis mulsa dan dosis pupuk NPK terhadap pertumbuhan dan hasil tanaman terong hijau, telah dilaksanakan di Desa Sukarara Kabupaten Lombok Tengah. Tujuan penelitian ini adalah untuk mengetahui: (1) pengaruh jenis mulsa terhadap pertumbuhan dan hasil tanaman terong hijau, (2) pengaruh dosis pupuk NPK terhadap pertumbuhan dan hasil tanaman terong hijau, (3) pengaruh interaksi jenis mulsa dan pupuk NPK terhadap pertumbuhan dan hasil terong hijau. Dalam penelitian ini digunakan rancangan faktorial yang terdiri atas 2 faktor. Faktor pertama adalah jenis mulsa dan faktor kedua adalah dosis pupuk NPK. Data penelitian dianalisis dengan analisis sidik ragam. Hasil penelitian menunjukkan bahwa (1) penggunaaan mulsa plastik hitam perak memberikan hasil yang lebih baik terhadap pertumbuhan dan hasil tanaman terong hijau dibandingkan mulsa jerami padi. (2) Perlakuan pupuk NPK dengan dosis 20 gram per tanaman meberikan pertumbuhan dan hasil tanaman terong hijau yang lebih baik dari pada perlakuan yang lain (3) interaksi jenis mulsa dan pupuk NPK berpengaruh nyata terhadap pertumbuhan dan hasil terong hijau. Petani yang menanam terong hijau direkombinasikan untuk menggunakan pupuk NPK dengan dosis 20 gram per tanaman
\end{abstract}

Kata kunci : mulsa, pupuk NPK, pertumbuhan dan hasil terong hijau

Abstract : Efforts to increase plant growth and yield can be done by using mulch and fertilizing plants. One synthetic fertilizer that can be used to increase plant growth and yield is NPK fertilizer. Research on the influence of the type of mulch and dosage of NPK fertilizer on the growth and yield of green eggplant, has been carried out in Sukarara Village, Central Lombok Regency. The purpose of this study is to find out: (1) the influence of the type of mulch on the growth and yield of green eggplant, (2) the effect of NPK fertilizer dosage on the growth and yield of green eggplant, (3) the influence of mulch and NPK fertilizer interactions on growth and yield of green eggplant. In this study a factorial design consisting of 2 factors was used. The first factor is the type of mulch and the second factor is the dose of NPK fertilizer. The research data were analyzed by variance analysis. The results of the study show that: (1) the use of black silver plastic mulch gives better results on the growth and yield of green eggplant than rice straw mulch. (2) The treatment of NPK fertilizer with a dose of 20 grams per plant gives better growth and yield of green eggplant plants than other treatments (3) interaction of mulch type and NPK fertilizer significantly affects the growth and yield of green eggplant. Farmers who grow green eggplant are recommended to use NPK fertilizer at a dose of 20 grams per plant

Keywords: mulch, NPK Fertilizer, growth and yield of green Eggplant 


\section{Bahan dan Metode}

Dalam upaya meningkatkan pertumbuhan dan hasil panen tanaman maka penyediaan unsur hara yang seimbang pada media tanam perlu dilakukan.oleh petani. Penyediaan unsur hara yang seimbang pada media tanam dapat dilakukan dengan pemupukan tanaman. Pemupukan tanaman dapat dilakukan dengan menggunakan pupuk sintetik maupun menggunakan pupuk organik (Zulkarnaen, 2014)

Salah satu pupuk sintetik yang dapat digunakan untuk meningkatkan pertumbuhan dan hasil panen tanaman adalah pupuk NPK. Hasil penelitian Raksun et al (2019) pada tanaman melon menunjukkan bahwa aplikasi pupuk NPK berpengaruh sangat nyata terhadap pertumbuhan vegetatif melon. Pemberian pupuk NPK mutiara berpengaruh nyata terhadap pertumbuhan dan produksi tanaman bawang merah. Perlakuan terbaik terdapat pada perlakuan $250 \mathrm{~g} /$ plot. menghasilkan tinggi tanaman tertinggi $35,28 \mathrm{~cm}$, jumlah daun perumpun 11,67 helai, jumlah anakan perumpun 8,08 anakan, produksi per tanaman $46,35 \mathrm{~g}$ dan produksi per plot $1,17 \mathrm{~kg}$ (Efendi et al., 2017). Tinggi tanaman, diameter batang, jumlah cabang produktif, jumlah daun, indeks luas daun, dan hasil panen tanaman terung memberikan respons positif terhadap aplikasi pupuk $\mathrm{N}, \mathrm{P}, \mathrm{K}$ (Firmansyah et al., 2017).

Upaya peningkatan pertumbuhan dan hasil panen tanaman juga dapat dilakukan dengan aplikasi mulsa pada lahan pertanian. Hasil penelitian yang dilakukan Anggraeni, et al (2017) pada tanaman tomat menunjukkan bahwa interaksi pupuk kandang 10 ton/ha dan mulsa jerami 10 ton/ha memberikan pengaruh terbaik terhadap parameter jumlah daun, jumlah buah per tanaman, hasil per ubinan dan hasil per hektar. Hasil produksi buah tomat terbanyak diperoleh sebesar 11,98 ton/ha. Selanjutnya hasil penelitian pada tanaman kedelai menunjukkan bahwa pemberian mulsa plastik hitam perak meningkatkan tinggi tanaman, jumlah cabang produktif per tanaman, berat 1.000 biji kering, berat kering brangkasan per tanaman dan berat biji kering per $\mathrm{m}^{2}$ (Nurbaiti, at al, 2017) Berdasarkan uraian diatas maka peneliti melakukan penelitian tentang pengaruh jenis mulsa dan dosis pupuk NPK terhadap pertumbuhan dan hasil terong hijau. Adapun Tujuan penelitian ini adalah untuk mengetahui (1) pengaruh jenis mulsa terhadap pertumbuhan dan hasil tanaman terong hijau, (2) pengaruh pupuk NPK terhadap pertumbuhan dan hasil tanaman terong hijau, (3) pengaruh interaksi jenis mulsa dan dosis pupuk NPK terhadap pertumbuhan pertumbuhan dan hasil tanaman terong hijau.
Penelitian ini telah dilaksanakan pada bulan Mei sampai dengan Oktober 2018 di Desa Sukarara Kecamatan Jonggat Kabupaten Lombok Tengah. Penelitian dilakukan pada lahan sawah seluas $300 \mathrm{~m}^{2}$. Tanaman terong hijau ditanam pada bedengan yang ditutupi mulsa plastik hitam perak dan mulsa jerami padi. Tiap bedengan memiiki ukuran panjang $20 \mathrm{~m}$ dan lebar $80 \mathrm{~cm}$. Selain penggunaan mulsa yang berbeda, tanaman terong hijau juga diberikan perlakuan pupuk NPK.

Bahan-bahan yang digunakan dalam penelitian ini adalah pupuk NPK, mulsa jerami padi, mulsa pelastik hitam perak, tanah sawah, benih tanaman terong hijau, ajir bambu dan air. Selanjutnya alat-alat yang digunakan adalah cangkul, ember plastik, parang, gelas ukur, alat tulis menulis, timbangan, parang, hand spreyer, artco dorong dan gunting.

Tahapan pelaksanaan penelitian ini adalah: (1) menyemaikan benih terong hijau menggunakan pot pembibitan, (2) membersihkan lahan dari sampah dan tanaman liar (gulma), (3) mengolah lahan dan membuat bedengan menggunakan cangkul, (4) memberikan mulsa plastik dan mulsa jerami padi pada bedengan lahan percobaan, (5) memberikan pupuk NPK sesuai dosis perlakuan, (6) menanam bibit terong hijau pada lahan percobaan, (7) mengukur parameter pertumbuhan dan parameter hasil panen tanaman terong hijau.

Rancangan penelitian yang digunakan adalah rancangan faktorial yang terdiri atas 2 faktor. Faktor pertama adalah jenis mulsa yaitu: $\mathbf{M}_{1}=$ Mulsa jerami padi dan $\mathrm{M}_{2}=$ mulsa pelastik hitam perak. Faktor kedua adalah dosis pupuk NPK yang terdiri atas 4 level, yaitu $\mathrm{P}_{0}=$ tanpa pemberian pupuk NPK (kontrol), $\mathrm{P}_{1}=$ pemberian 10 gram pupuk NPK per tanaman, $\mathrm{P}_{2}=$ pemberian 20 gram pupuk NPK per tanaman dan $\mathrm{P}_{3}=$ pemberian 30 gram pupuk NPK per tanaman. Setiap kombinasi perlakuan dilakukan dengan 4 ulangan, dengan kombinasi perlakuan sebagai berikut:

\begin{tabular}{|l|l|l|l|l|}
\hline Perlakuan & $\mathrm{P}_{0}$ & $\mathrm{P}_{1}$ & $\mathrm{P}_{2}$ & $\mathrm{P}_{3}$ \\
\hline $\mathrm{M}_{1}$ & $\mathrm{M}_{1} \mathrm{P}_{0}$ & $\mathrm{M}_{1} \mathrm{P}_{1}$ & $\mathrm{M}_{1} \mathrm{P}_{2}$ & $\mathrm{M}_{1} \mathrm{P}_{3}$ \\
\hline $\mathrm{M}_{2}$ & $\mathrm{M}_{2} \mathrm{P} 0$ & $\mathrm{M}_{2} \mathrm{P}_{1}$ & $\mathrm{M}_{2} \mathrm{P}_{2}$ & $\mathrm{M}_{2} \mathrm{P}_{3}$ \\
\hline
\end{tabular}

Parameter pertumbuhan yang diukur adalah panjang daun, lebar daun, dan tinggi batang yang dilakukan setelah tanaman berumur 65 hari. Parameter hasil yang diukur adalah panjang dan berat buah terong hijau. Data kuantitatif hasil pengukuran parameter pertumbuhan dan hasil terong hijau dianalisis dengan analisis sidik ragam (Teutenburg and Shalabh. 2009). 
Raksun, A. et al., Jurnal Biologi Tropis, 19 (2) : 142 - 146

DOI: $10.29303 /$ jbt.v19i2.1115

\section{Hasil dan Pembahasan \\ Pertumbuhan Tanaman Terong Hijau}

Hasil pengukuran tinggi batang terong hijau pada umur 68 hari setelah tanam menunjukkan bahwa rerata tinggi batang terong hijau tertinggi adalah $68 \mathrm{~cm}$ terdapat pada perlakuan $\mathrm{M}_{2} \mathrm{P}_{3}$ yaitu tanaman terong hijau yang ditanam pada lahan yang ditutup mulsa plastik hitam perak dan diberikan 20 gram pupuk NPK per tanaman. Tinggi batang tanaman terong hijau terendah adalah $44 \mathrm{~cm}$ yaitu terong hijau yang ditanam pada media yang ditutup mulsa jerami padi dan tindak diberikan pupuk NPK. Hasil analisis sidik ragam menunjukkan bahwa Perbedaan jenis mulsa berpengaruh nyata terhadap tinggi batang tanaman terong hijau. Perbedaan dosis pupuk NPK berpengaruh nyata terhadap tinggi batang tanaman terong hijau. Interaksi jenis mulsa dan dosis pupuk NPK berpengaruh nyata terhadap tinggi batang tanaman terong hijau. Data hasil pengukuran tinggi batang tanaman terong hijau disajikan pada tabel 1 .

Tabel 1. Rerata Tinggi Batang Tanaman Terung Hijau Akibat Perbedaan Jenis Mulsa dan Dosis Pupuk NPK pada Umur 68 Hari Setelah Tanam

\begin{tabular}{|c|c|c|c|}
\hline Perlakuan & $\begin{array}{c}\text { Rerata } \\
\text { Tinggi } \\
\text { Batang } \\
(\mathrm{cm})\end{array}$ & Perlakuan & $\begin{array}{c}\text { Rerata } \\
\text { Tinggi } \\
\text { Batang } \\
(\mathrm{cm})\end{array}$ \\
\hline $\mathrm{M}_{1} \mathrm{P}_{0}$ & 44 & $\mathrm{M}_{2} \mathrm{P}_{0}$ & 50 \\
\hline $\mathrm{M}_{1} \mathrm{P}_{1}$ & 47 & $\mathrm{M}_{2} \mathrm{P}_{1}$ & 58 \\
\hline $\mathrm{M}_{1} \mathrm{P}_{2}$ & 56 & $\mathrm{M}_{2} \mathrm{P}_{3}$ & 68 \\
\hline $\mathrm{M}_{1} \mathrm{P}_{3}$ & 55 & $\mathrm{M}_{2} \mathrm{P}_{3}$ & 66 \\
\hline
\end{tabular}

Data hasil pengukuran panjang daun tanaman terong hijau pada tabel 2 menunjukkan bahwa rerata panjang daun tanaman terong hijau tertinggi adalah $30 \mathrm{~cm}$ terdapat pada perlakuan mulsa plastik hitam perak dan 20 gram pupuk NPK per tanaman $\left(\mathrm{M}_{2} \mathrm{P}_{3}\right)$. Selanjutnya panjang daun terong hijau terendah adalah $21 \mathrm{~cm}$ yaitu pada tanaman yang diberi perlakuan mulsa jerami padi dan o gram pupuk NPK $\mathrm{M}_{1} \mathrm{P}_{0}$. Analisis sidik ragam menunjukkan bahwa perbedaan jenis mulsa berpengaruh nyata terhadap panjang daun, Perlakuan pupuk NPK berpengaruh nyata terhadap panjang daun. Interaksi jenis mulsa dan dosis pupuk NPK berpengaruh nyata terhadap panjang daun tanaman terong hijau.

Tabel 2. Rerata Panjang Daun Tanaman Terung Hijau Akibat Perbedaan Jenis Mulsa dan Dosis Pupuk NPK pada Umur 68 Hari Setelah Tanam

\begin{tabular}{|c|c|c|c|}
\hline Perlakuan & $\begin{array}{c}\text { Rerata } \\
\text { Panjang } \\
\text { Daun }(\mathrm{cm})\end{array}$ & Perlakuan & $\begin{array}{c}\text { Rerata } \\
\text { Panjang } \\
\text { Daun }(\mathrm{cm})\end{array}$ \\
\hline $\mathrm{M}_{1} \mathrm{P}_{0}$ & 21 & $\mathrm{M}_{2} \mathrm{P}_{0}$ & 25 \\
\hline $\mathrm{M}_{1} \mathrm{P}_{1}$ & 24 & $\mathrm{M}_{2} \mathrm{P}_{1}$ & 28 \\
\hline $\mathrm{M}_{1} \mathrm{P}_{2}$ & 27 & $\mathrm{M}_{2} \mathrm{P}_{3}$ & 30 \\
\hline $\mathrm{M}_{1} \mathrm{P}_{3}$ & 26 & $\mathrm{M}_{2} \mathrm{P}_{3}$ & 28 \\
\hline
\end{tabular}

Hasil analisis data menunjukkan bahwa perbedaan jenis mulsa berpengaruh nyata terhadap pertumbuhan tanaman terong hijau. Perlakuan mulsa plastik hitam perak memberikan hasil yang lebih baik dibandingkan dengan perlakuan mulsa jerami padi. Hasil penelitian ini sejalan dengan hasil penelitian yang dilakukan oleh Mahmudi at al (2017) yang menyimpulkan bahwa macam mulsa berpengaruh terhadap tinggi tanaman, jumlah daun, jumlah umbi per rumpun, berat segar umbi per rumpun, berat umbi kering simpan per rumpun bawang merah. Penggunaan mulsa plastik hitam perak menghasilkan tanaman yang paling tinggi, jumlah daun dan jumlah umbi per rumpun yang paling banyak, serta berat segar umbi per rumpun dan berat umbi kering simpan per rumpun yang paling berat.

Perbedaan dosis pupuk NPK juga berpengaruh nyata terhadap pertumbuhan tanaman terong hijau. Hal ini desebabkan karena unsur hara Nitrogen, Fosfor dan Kalium merupakan unsur hara makro yang diperlukan untuk pertumbuhan tanaman. Lingga dan Marsono (2013) menjelaskan bahwa unsur hara nitrogen merupakan komponen penyusun asam amino, protein dan pembentukan protoplasma sel yang dapat berfungsi dalam merangsang pertumbuhan tanaman. Fosfor berperan terhadap pembelahan sel pada titik tumbuh yang berpengaruh pada tinggi tanaman. Hasil penelitian ini sejalan dengan hasil penelitian Waris dan Fathia (2010), bahwa pupuk NPK berpengaruh nyata terhadap pertumbuhan tinggi dan diameter batang. Perlakuan kombinasi NPK 10 gr dan kompos 30 gr memberikan pengaruh paling nyata dan respon pertumbuhan tertinggi terhadap kontrol yaitu 70,08\% atau setara dengan ratarata pertumbuhan sebesar $7,56 \mathrm{~cm}$ terhadap kontrol.

\section{Hasil Panen Terong Hijau}

Para meter hasil panen yang diukur adalah panjang buah dan berat basah buah terong hijau. Data hasil pengukuran panjang buah terong hijau menunjukkan bahwa panjang buah tertinggi adalah $31 \mathrm{~cm}$ terdapat pada tanaman yang diberi perlakuan mulsa plastik hitam perak dan 20 gram pupuk NPK. Panjang buah terendah adalah $16 \mathrm{~cm}$ (perlakuan mulsa jerami padi dan 0 gram pupuk NPK). Analisis sidik ragam menunjukkan bahwa perbedaan jenis mulsa berpengaruh nyata terhadap panjang buah, Perlakuan pupuk NPK berpengaruh nyata terhadap panjang buah. Interaksi jenis mulsa dan dosis 
Raksun, A. et al., Jurnal Biologi Tropis, 19 (2) : 142 - 146 DOI: $10.29303 /$ jbt.v19i2.1115

pupuk NPK berpengaruh nyata terhadap panjang buah tanaman terong hijau.

Tabel 3. Rerata Panjang Buah Tanaman Terung Hijau Akibat Perbedaan Jenis Mulsa dan Dosis Pupuk NPK

\begin{tabular}{|c|c|c|c|}
\hline Perlakuan & $\begin{array}{c}\text { Rerata } \\
\text { Panjang } \\
\text { Buah }(\mathrm{cm})\end{array}$ & Perlakuan & $\begin{array}{c}\text { Rerata } \\
\text { Panjang } \\
\text { Buah }(\mathrm{cm})\end{array}$ \\
\hline $\mathrm{M}_{1} \mathrm{P}_{0}$ & 16 & $\mathrm{M}_{2} \mathrm{P}_{0}$ & 24 \\
\hline $\mathrm{M}_{1} \mathrm{P}_{1}$ & 19 & $\mathrm{M}_{2} \mathrm{P}_{1}$ & 27 \\
\hline $\mathrm{M}_{1} \mathrm{P}_{2}$ & 23 & $\mathrm{M}_{2} \mathrm{P}_{3}$ & 31 \\
\hline $\mathrm{M}_{1} \mathrm{P}_{3}$ & 25 & $\mathrm{M}_{2} \mathrm{P}_{3}$ & 29 \\
\hline
\end{tabular}

Hasil pengukuran berat basah buah terong hijau tertinggi adalah 624 gram diperoleh pada tanaman yang diberi perlakuan mulsa plastik hitam perak dan 20 gram pupuk NPK, terendah pada perlakuan mulsa jerami padi dan 0 gram pupuk NPK sebesar 468 gram. Analisis sidik ragam menunjukkan bahwa perbedaan jenis mulsa berpengaruh nyata terhadap berat basah buah. Perlakuan pupuk NPK berpengaruh nyata terhadap berat basah buah. Interaksi jenis mulsa dan dosis pupuk NPK berpengaruh nyata terhadap berat basah buah terong hijau.

Tabel 4. Rerata Berat Basah Buah Terung Hijau Akibat Perbedaan Jenis Mulsa dan Dosis Pupuk NPK

\begin{tabular}{|c|c|c|c|}
\hline Perlakuan & $\begin{array}{c}\text { Berat } \\
\text { Basah } \\
\text { Buah } \\
\text { gram })\end{array}$ & Perlakuan & $\begin{array}{c}\text { Berat } \\
\text { Basah } \\
\text { Buah } \\
\text { gram })\end{array}$ \\
\hline $\mathrm{M}_{1} \mathrm{P}_{0}$ & 468 & $\mathrm{M}_{2} \mathrm{P}_{0}$ & 512 \\
\hline $\mathrm{M}_{1} \mathrm{P}_{1}$ & 482 & $\mathrm{M}_{2} \mathrm{P}_{1}$ & 578 \\
\hline $\mathrm{M}_{1} \mathrm{P}_{2}$ & 535 & $\mathrm{M}_{2} \mathrm{P}_{3}$ & 624 \\
\hline $\mathrm{M}_{1} \mathrm{P}_{3}$ & 576 & $\mathrm{M}_{2} \mathrm{P}_{3}$ & 618 \\
\hline
\end{tabular}

Hasil analisis data menunjukkan bahwa perbedaan jenis mulsa berpengaruh nyata terhadap hasil panen tanaman terong hijau. Perlakuan mulsa plastik hitam perak memberikan hasil yang lebih baik dibandingkan dengan perlakuan mulsa jerami padi. Hasil penelitian ini sejalan dengan hasil penelitian Rianto at al (2017) menyimpulkan bahwa perbedaan jenis mulsa dan dosis Gandail-B berpengaruh nyata terhadap semua komponen hasil tanaman cabai rawit, Penggunaan mulsa plastik hitam perak dan pemberian pupuk gandasil-B dengan dosis 3 gram per liter air menghasilkan jumlah cabang produktif (14,00 cabang) dan jumlah buah paling banyak (151,17 buah) serta meningkatkan berat buah. Selanjutnya disimpulkan bahwa penggunaan mulsa dapat meningkatkan panjang tanaman, berat buah, lingkar buah, berat segar, dan berat kering buah semangka. Hasil terbaik adalah perlakuan mulsa plastik hitam perak dengan panjang tanaman $353,98 \mathrm{~cm}$, dan berat buah 5,47 kg ( Junaidi et al., 2013).

Perbedaan dosis pupuk NPK juga berpengaruh nyata terhadap hasil panen tanaman teorng hijau. Lakitan (2000) menyatakan bahwa unsur hara P berperan dalam fotosintesis, respirasi dan metabolisme lainnya yang mendorong laju pertumbuhan tanaman. Jika tanaman kekurangan unsur $\mathrm{P}$, pembelahan selnya terhambat dan pertumbuhan kerdil. Unsur $\mathrm{K}$ berfungsi sebagai activator enzim dalam pembentukan protein dan karbohidrat, membentuk batang yang lebih kuat serta memperkuat perakaran.

Hasil penelitian Idha dan Herlina (2018) pada tanaman selada merah menunjukkan bahwa perlakuan pupuk kandang dan 3 gram pupuk NPK memberikan pertumbuhan terbaik dengan bobot segar konsumsi terbaik pula yaitu 118,10 gram per tanaman. Ada interaksi antara pupuk nitrogen dan pupuk kalium terhadap tinggi tanaman, jumlah daun, bobot umbi basah dan kering tanaman bawang merah. Kombinasi pupuk nitrogen dengan dosis $250 \mathrm{~kg}$ per hektar dan pupuk kalium dengan dosis $100 \mathrm{~kg}$ per hektar menghasilkan bobot umbi kering tertinggi yaitu 64,69 gram per rumpun (Napitulu dan Winarto, 2010)

\section{Kesimpulan}

Berdasarkan hasil analisis data dan pembahasan pada penelitian ini maka dapat disimpulkan bahwa: (1) Perbedaan jenis mulsa berpengaruh nyata terhadap pertumbuhan dan hasil terong hijau, mulsa plastik hitam perak memberikan pertumbuhan dan hasil panen yang lebih baik dibandingkan dengan mulsa jerami padi, (2) Dosis pupuk NPK berpengaruh nyata terhadap pertumbuhan dan hasil terong hijau, (3) Interaksi jenis mulsa dan dosis pupuk NPK berpengaruh nyata terhadap pertumbuhan dan hasil terong hijau. (4) Perlakuan pupuk NPK dengan dosis 20 gram per tanaman meberikan pertumbuhan dan hasil tanaman terong hijau yang lebih baik dari pada perlakuan lainnya.

\section{Ucapan Terima Kasih}

Terima kasih yang sebesar-besarnya kami sampaikan kepada Rektor Universitas Maaram yang telah memfasilitasi penyediaan dana penelitian sehingga penelitian ini dapat dilaksanakan sesuai waktu dan tahapan keja yang telah direncanakan.

\section{Daftar Pustaka}

Anggraeni, R., A. Hadid \& S. Laude (2017). Pemanfaatan Mulsa dan Pupuk Kandang terhadap Pertumbuhan dan Hasil Tanaman Tomat (Lycopersicum esculentum Mill.). Agroland, 24 (1) : $64-72$ 
Efendi, E., D. W. Purba \& N.H. Nasution (2017). Respon Pemberian Pupuk NPK Mutiara dan Bpkashi Jerami Padi terhadap Pertumbuhan dan Produksi Tanaman bawang Merah (Allium ascalonicum L). Penelitian Pertanian BERNAS, 13 (3): 20 - 30

Idha, M.E. \& Herlina, N. (2018). Pengaruh Macam Media Tanam dan Dosis Pupuk NPK terhadap Pertumbuhan dan Hasil Tanaman Selada Merah (Lactuca sativa var. Crispa). Produksi Tanaman, 6 (4) : $398-402$

Firmansyah, I., M. Syakir \& L. Lukman (2017). Pengaruh Kombinasi Dosis Pupuk N, P, dan K Terhadap Pertumbuhan dan Hasil Tanaman Terung (Solanum melongena L.). J. Hort, 7 (1): $69-78$

Junaidi I., Santoso, S.J. \& Sudalmi, E.S. (2013). Pengaruh Macam Mulsa dan Pemangkasan terhadap Pertumbuhan dan Hasil Tanaman Semangka. Inovasi Pertanian, 12 (2) : $67-84$

Lakitan B. (2000). Dasar-Dasar Fisiologi Tumbuhan. Raja Grafindo Persada. Jakarta.

Lingga, P. \& Marsono (2013). Petunjuk Penggunaan Pupuk. Penebar Swadaya. Jakarta.

Mahmudi, S., H. Rianto \& Historiawati (2017). Pengaruh Mulsa Plastik Hitam Perak dan Jarak Tanam pada Hasil Bawang Merah (Allium cepa fa. ascalonicum, L.). Varietas Biru Lancor. Ilmu Pertanian Tropika dan Subtropika, 2 (2) : $60-62$
Napitulu, D. \& L. Winarto (2010). Pengaruh Pemberian Pupuk $\mathrm{N}$ dan $\mathrm{K}$ terhadap Pertumbuhan dan Produksi Bawang Merah. J. Hort, 10 (10: 27 - 35

Nurbaiti, F., G. Haryono \& A. Suprapto (2017). Pengaruh Pemberian Mulsa dan Jarak Tanam pada Hasil Tanaman Kedelai (Glycine max, L. Merrill.) Var. Grobokan. Ilmu Pertanian Tropika dan Subtropika, 2 (2) : 41 - 47

Raksun, A., L. Japa \& I.G. Mertha (2019). Aplikasi Pupuk Organik dan NPK untuk Meningkatkan Pertumbuhan Vegetatif Melon (Cucumis melo L.). Jurnal Biologi Tropis, 19 (1): 19 - 24

Rinoto, Winarti \& Salampak (2017). Pengaruh Jenis Mulsa dan Pupuk Gandasil-B Terhadap Pertumbuhan dan Hasil Tanaman Cabai Rawit (Capsium frustescens L.) pada tanah Lapang. Agri Peat, 18 (1): 1 -9

Sunarjono. H. (2013). Bertanam 30 Jenis Sayuran. Penebar Swadaya. Jakarta.

Teutenburg, H. \& Shalabh (2009). Statistical Analysis of Designed Experiment. Third Edition. Springer. New York

Waris, B. \& Fathia, N. (2010). Pengaruh Pupuk NPK dan Kompos terhadap Pertumbuhan Semai Gmelina pada Media Tanah Bekas Tambang Emas (Tailing). Ilmu Pertanian Indonesia, 16 (2): $123-129$

Zulkarnain (2014). Dasar-Dasar Hortikultura. Bumi Aksara. Jakarta 